\title{
The Normalization of Exclusion through a Revival of Whiteness in Donald Trump's 2016 Election Campaign Discourse
}

\author{
Frank Austermuehl
}

School of Languages and Social Sciences, Aston University, Birmingham, UK

Aston Triangle, Birmingham B4 7ET, UK

Frank Austermuehl is Professor of Modern Languages at Aston University in Birmingham, UK. A former Fulbright fellow at the Library of Congress in Washington, DC, and the University of Virginia in Charlottesville, VA, he is the author of The Great American Scaffold -Intertextuality and Identity in American Presidential Discourse (Benjamins 2014). Frank has a $\mathrm{Ph} . \mathrm{D}$. from the University of Heidelberg and has previously taught at the Universities of Heidelberg and Mainz in Germany and the University of Auckland in New Zealand. He is currently working on a book on American presidential campaign discourse. 


\title{
The Normalization of Exclusion through a Revival of Whiteness in Donald Trump's 2016 Election Campaign Discourse
}

\author{
This article is based on the thesis that the language employed during the Trump \\ campaign and the narrative created in his public speeches and social media posts \\ played a decisive role in increasing white voter turnout and thus contributed to a \\ significant extent to Trump's victory. I argue that Trump won the presidency not \\ despite having run what the Washington Post called "the most racist, xenophobic, \\ misogynistic campaign for president in memory," but because of it. The often \\ openly abusive, hateful, and nativist discourse of the Trump campaign is the \\ result of a strategic decision to create a winning coalition, a new, old covenant, of \\ white Americans eager to reinstate a vision of a pre-diversity America. In his \\ campaign speeches, Trump employed a number of discursive strategies that \\ supported the normalization of verbal behavior that was previously seen as either \\ utterly unacceptable or at least politically incorrect. These include, among others, \\ the creation of fear, racialization, discrimination, stigmatization and de- \\ stigmatization, scapegoating and victimization, as well as othering and social \\ exclusion. All of these strategies need to be seen against the background of \\ discursively constructed imaginaries of whiteness where the exclusion of un- \\ American others in Trump's campaign discourse is closely linked with an \\ articulation of America as a white nation.
}

Keywords: American jeremiad; campaign discourse; Donald J. Trump; normalization; othering; political correctness; whiteness

\section{Introduction}

On June 16, 2015, Donald J. Trump announced his intention to run for the office of President of the United States. Speaking in the lavish lobby of Trump Tower on New York's Fifth Avenue, the reality-TV star and billionaire real-estate mogul gave the public a first glimpse at how he intended to "Make American Great Again," and a first taste of the language he intended to use in his ultimately successful campaign. As the Guardian newspaper writes, Trump "had been waging what many saw as a racist 'birther' campaign against Barack Obama for years, falsely claiming the then president 
had been born in Kenya. But even for close Trump watchers, the speech represented new extremes" (Gabbatt 2019). Within less than two minutes into his speech, Trump claimed that

When Mexico sends its people, they're not sending their best. They're not sending you. They're sending people that have lots of problems, and they're bringing those problems with them. They're bringing drugs. They're bringing crime. They're rapists. And some, I assume, are good people. (Announcement)

Verbal attacks on immigrants and foreigners became a staple of Trump's America First discourse, which established a causal relationship between illegal immigration and violent crimes and conjured up the threatening image of "millions more illegal immigrants; thousands of more violent, horrible crimes; and total chaos and lawlessness" (Immigration).

If we understand normalization as the strategic use of "language which pre/legitimises views, ideologies and positions that were until recently treated as radical and socially unacceptable" (Krzyżanowski 2020, 1), then Trumps' campaign speeches warrant particular scrutiny.

This article is based on the thesis that the language employed during the Trump campaign and the narrative created in his public speeches and social media posts played a decisive role in increasing white voter turnout and thus contributed to a significant extent to Trump's victory. In this context, the normalization of previously unacceptable discursive behavior played a significant role. I will further argue that Trump won the presidency not despite having run what the Washington Post called "the most racist, xenophobic, misogynistic campaign for president in memory" (Capehart 2017), but because of it. The often openly abusive, hateful, and nativist discourse of the Trump campaign was the result of a strategic decision to create a winning coalition, a new, old covenant of white Americans eager to reinstate a largely imaginary vision of a pre- 
diversity America. By tapping into a deep well of existing prejudice and fear, Trump's exclusionary discourse created an in-group united as much by economic resentment as by cultural anxieties.

One of the pillars of the success of Trump's discourse was his ability to capture the needs of a community of 'American sufferers' and first feed, through a language of fear, their existing social, cultural, and economic anxieties, and then transform the latter into anger and political action. This in-group - the demographic backbone of Trump's electoral college victory_proved particularly susceptible to the nativist and anti-elitist message of Trump's campaign discourse and was overwhelmingly composed of white Americans, in particular, but not exclusively, non-college educated whites, both male and female.

Trump laid the blame for the nation's troublesome state at the feet of the country's governing economic, political, and media elites. This scapegoating technique did not only absolve Trump voters from any potential blame for their own situation but also gave them a target in the form of Hillary Clinton that they could focus their anger on. By portraying Americans as victims of a global conspiracy and treason at the highest levels of the American political establishment, Trump victimized his voters and converted their anxieties into political motivation.

Trump employed a number of discursive strategies that supported the normalization of verbal behavior that had previously been considered either utterly unacceptable or at least politically incorrect. These include, among others, the creation of fear, racialization, discrimination, stigmatization and de-stigmatization, scapegoating and victimization, as well as othering and social exclusion. All of these strategies need to be seen against the background of discursively constructed imaginaries of whiteness. The exclusion of un-American others is closely linked with an articulation of America 
as a white nation. Here, Trump's announcement speech represents a turning point in political campaign discourse and the beginning of the end of discursive decency. As Burleigh (2019) states, "by declaring Mexican immigrants 'rapists' on the first day of his campaign, he promoted an us-vs.-them worldview and found a political vein other politicians had not dared tap_or, if they had, only gingerly: whiteness."

As I discuss in greater detail elsewhere (Austermuehl 2019), Trump framed his ethno-nativist vision of America and his attacks on the anti-white establishment almost entirely, and very consistently, in the form of the American jeremiad (Bercovitch 2012), a type of political and religious discourse that arrived in America with the first Puritan pilgrims. Adopting the logic of the jeremiad allows candidates to don the mantle of the political prophet who laments the nation's tribulations, blames the current leaders for the nation's sorrow state, absolves the people of any blame for their troubles, and offers himself as the solution to all the problems. Understanding the cultural tradition of the jeremiad and its recontexualization in modern U.S. presidential campaigns is key to understanding how normalization happens, i.e., how Trump's deliberate and strategic use of language not only "disrupted political and discourse norms" (Jamieson and Taussig 2017, 649) but also enabled him to "present[] 'uncivil' ideas related to unacceptable norms of social conduct - such as e.g. racism, discrimination etc. - as legitimate and acceptable (Krzyżanowski 2020, 11).

In the following, I will first provide some context regarding the 2016 election, focusing, in particular, on voter turnout rates and candidate preferences by race and class. Following this, I will discuss the methodology supporting this study and then analyze the main normalization strategies evident in Trump's campaign discourse 
strategies against the background of the American jeremiad. ${ }^{1}$ I will conclude with an outlook to the 2020 U.S. presidential election campaign.

\section{$2 \quad$ America's "First White President"}

Explaining why exactly Trump ended up winning the 2016 election is not a simple task. Reasons why Trump did much better than expected, and why his opponent Hillary Clinton was not able to sustain her leads in pre-election opinion polls, are plentiful, starting with the poor quality of the opinion polls themselves (Kennedy et al. 2018), and continuing, among many others, with Trump's focus on traditional Republican themes, such as taxes, military spending, gun laws, and abortion (Hanson 2016), Clinton's lackluster campaigning (Stein 2017), the FBI's investigation into Clinton's misuse of private e-mail (McElwee, McDermott, and Jordan 2017), Russian meddling (Lichtblau 2017), and more restrictive voter registration laws that discriminated against black voters (Newkirk 2018).

Nevertheless, in an election effectively decided by 77,744 votes-i.e., the combined winning margin for the three states of Michigan, Pennsylvania, and Wisconsin that gave Trump the majority in the Electoral College- it is safe to assume that superior turnout among Trump voters, in particular among rural and working-class whites, and the sizeable group of white Obama-to-Trump voters are at the core of Trump's victory. Increasing voter turnout is no small task; indeed, it represents, as Newsweek magazine puts it, "the Holy Grail" of political campaigning (Goodman 2014).

\footnotetext{
${ }^{1}$ While, at times, I will refer to Trump's use of Twitter, this analysis is primarily based on formal campaign speeches (see Section 3 for details on the corpus used). For Trump and Twitter, see Smith and Higgins 2020.
} 
Understanding how Trump managed to ensure that the members of the demographic group that constituted the vast majority of his voters, i.e., white men and women, often without a college degree, often belonging to the rural and working classes of America, showed up on Election Day and voted for him is crucial not only to explaining Trump victory in 2016 but also to what kind of campaign we can expect for the 2020 U.S. presidential elections.

Overall, the 2016 turnout was "not statistically different from the 61.8 percent who reported voting in 2012." However, when considering voters' race and taking a more diachronic perspective, a different picture emerges. According to the U.S. Census Bureau, "voting rates have historically varied by race and Hispanic origin. In 2012, voting rates for non-Hispanic blacks (66.6 percent) were higher than non-Hispanic whites (64.1 percent) for the first time [since 2000]. In 2016, turnout increased to 65.3 percent for non-Hispanic whites, but decreased to 59.6 percent for non-Hispanic blacks" (File 2017, 1).

The consequences of the decline in the numbers of voters that formed Obama's winning rainbow coalition (and of which Clinton won a smaller share than Obama) is intensified by parallel increases in the number of members of Trump's white coalition. The writer Ta-Nehisi Coates summed up the importance of white voter by referring to Trump as "America's first white president." As Coates explains, "in 2016, Trump enjoyed majority or plurality support among every economic branch of whites. Trump won white voters with and without a college degree. He won both white men (63 percent) and women (53 percent) [...] and all age groups of whites" (Coates 2017). The only group of white voters that Trump did not win were college-educated women, who made up about 20 per cent of the total vote and favored Clinton by 51 per cent over 44 per cent. Overall, though, Clinton, the first female major-party candidate for president 
"was not broadly more appealing to women than previous Democrats. And, in fact, she did worse with noncollege white women than a black man did four years earlier" (Yglesias 2017).

The size of the advantage of Trump's victory among white voters was significant, including in the rust belt swing states that secured Trump's electoral college victory. "Turnout for Pennsylvania's white voters went up significantly; white college graduate turnout was up 3 points and white non-college-graduate turnout was up more than 4 points" (Griffin, Teixeira, and Halpin 2017, 9). In Wisconsin, white voter turnout dropped by about two per cent, but was eclipsed by a 19-point drop in black voter turnout (11).

A total of five million white voters, i.e., 12.7 per cent of all white voters who supported Obama in 2012 voted for Trump in 2016. These Obama-Trump voters "were disproportionately white and members of the working class." In addition, "eligible nonvoters in 2012 were also a substantial portion of Trump's voters in 2016, and they were disproportionately white" (Morgan and Lee 2018, 238).

In the aftermath of the 2016 election, a number of political commentators pointed to Trump's ability to "activate" white voters as having been essential to his narrow victory. Newsweek journalist Nina Burleigh (2018) wrote, "Trump, with his pledge to "make America great again," activated the equivalent of a political sleeper cell. Not surprisingly, the data finds a strong correlation between "white identity" and support for the candidate in the red MAGA hat."

\section{$3 \quad$ Methodology}

The following analysis of how Trump's discourse in general and his use of a set of normalization strategies in particular contributed to his electoral success is informed by Critical Discourse Analysis (CDA) and its interest in the construction of identities and 
the establishment of political power relationships (see, for example, Fairclough 1992 and van Dijk 2008). The study also relies on Corpus Linguistics (CL) and is both corpus-based and corpus-driven, combining quantitative and qualitative forms of computer-assisted analysis with the close reading of selected campaign speeches (see Baker et al. 2008).

The analysis of Trump's campaign discourse and the strategies of normalization applied is based on two corpora, which are used in a complementary manner. In line with the combined CL-CDA approach mentioned above, the critical analysis of Trump's discourse is based on an in-depth study of nine major campaign speeches (including the Inaugural Address; see Appendix 1). The total number of words in this corpus is 35,211. The selected speeches in the first corpus reflect the normal life cycle of presidential campaigns in the United States. The official beginning of the campaign comes in the form of the candidacy announcement. The nomination acceptance speech, delivered during the Republican National Convention, represents the climax of the primary election season and, at the same time, serves as the official opening of the general election campaign. The victory speech completes the election process and signifies the beginning of the transition period. The inaugural address, finally, completes the campaign and intends to re-unite the populace (Campbell and Jamieson 2008).

The remaining five speeches in the close-reading sub-corpus were selected due to their temporal coverage of the entire election cycle, their respective lengths, the main topics they covered, and the amount of media coverage they created. They can all be considered as substantial and impactful campaign speeches. The nine speeches in this corpus will be referred to by their (shortened) title.

The second corpus consists of 74 speeches (including eight of the speeches mentioned above, but excluding the inaugural address; see Appendix 2) given by Trump 
during the 2016 primary and general election campaigns, starting with his candidacy announcement of June 2015 and ending with the victory speech in the early hours of November 9, 2016. The total number of words in this corpus is 230,764 . The speeches in this corpus will be referred to by the place and date they were given. The texts of all speeches are taken from the University of California at Santa Barbara's American Presidency Project website (https://www.presidency.ucsb.edu).

The computer-assisted analysis of the larger corpus_aimed at complementing the critical analysis of the smaller corpus - focuses on the identification of specific linguistic patterns and their related normalization strategies through the analysis of, e.g., collocations and word clusters (n-grams) of selected keywords, such as, e.g., "kill," "murder," "immigrant(s)" or "worker(s)."

In line with my previous interpretation of Trump's campaign discourse as a recontextualized jeremiad, I will structure the presentation and discussion of the results of the corpus analysis according to the narrative logic of the jeremiad, merging the latter with a description of the normalization logic inherent to Trump's discourse.

\section{Normalizing Bigotry: The Uncivil Discourse of Donald Jeremiah}

\section{Trump}

As I discuss in greater detail elsewhere (Austermuehl 2019), Trump framed his ethnonativist vision of America and his attacks on the anti-white establishment almost entirely, and very consistently, in the form of the American jeremiad, a type of political and religious discourse that arrived in America with the first Puritan pilgrims. Seeing Trump's normalization discourse through the lens of the American jeremiad will add an important historical dimension to the analysis of his discourse and will also help understanding why this genre is particular suitable for employing what Krzyżanowski and Ledin (2017) call "borderline discourses." 
The jeremiad takes its name from the prophet Jeremiah, who preached against greedy priests and false prophets, who catalogued Israel's fall from fidelity and warned of the horrible judgments to come. In the early days of the New England colonies, jeremiads were often employed in reaction to some sort of crisis, e.g., a drought, a fire, or an Indian attack. Puritan church leaders used passages from the Book of Jeremiah or his Book of Lamentations to present these tribulations as God's punishment for moral problems in their community, and then called for repentance and the renewal of the group's original covenant with God. This is backed by a promise that God would not forsake them if they returned to him.

Over time, the jeremiad developed into a kind of rhetorical Swiss-army knife applied in such diverse contexts as the anti-slavery movement, women's voting rights, the prohibition, the Civil rights struggle, and political election campaigns. By employing the jeremiad as an "indictment" (Kaveny 2016), Trump was able to successfully tap into the conscious and subconscious experiences of American voters, simultaneously 1) lamenting the current disastrous economic and emotional state of a country under siege at home and ridiculed abroad; 2) laying the blame for this "American carnage" (Inaugural) on a cabal of un-American others (Mexican rapists, Islamic terrorists, treacherous special interests, treasonous politicians, stupid leaders, a lying secretary of state, etc.); 3) establishing himself as the ultimate political outsider, a new American Cincinnatus, as the successful, strong businessman, the male protector of the true American people; and thus 4) presenting himself as the only solution—("I alone can fix this") - to the tribulations that his people, misled by the false prophets of past administrations, are experiencing.

The steps of the jeremiad are closely aligned with and supported by a number of normalization strategies. The description of the tribulations afflicting the nation aims at 
the creation of physical and economic fear (see Wodak 2015) and an overall sense of "moral panic" (see Cohen 1972/2002 and Krzyżanowski 2020). The fear mongering is often accompanied by the use of racialized, discriminatory language, which is also present during the jeremiad's second stage, where the prophet identifies and condemns the scapegoats who are to be blamed for the nation's problems. The description of these scapegoats is full of stereotypes and stigmata, while the 'true' people, the prophet's future voters, are victimized, destigmatized, and generally absolved of any blame for the circumstances in which they find themselves. The scapegoating ultimately leads to the creation of in-groups and out-groups and to the social exclusion of those not belonging to the in-group of the chosen people. The prophet's self-portrait as a political outsider is supported by claims of authenticity, which is evidenced by the use of plain language.

\subsection{American Wasteland}

The first step of the campaign jeremiad consists in listing and describing in great and vivid detail the troubles that the nation is currently facing. From the onset, Trump makes clear that the stakes are high, telling the Republican National Convention that "we meet at a moment of crisis for our nation. The attacks on our police, and the terrorism in our cities, threaten our very way of life" (Nomination Acceptance) and proclaiming "a struggle for the survival of our nation" (West Palm Beach).

Trump organizes his utterly negative narrative of the state of the American nation around two realms, the domestic and the international. Domestically, he conjures up the image of an American wasteland, a dystopian landscape of industrial ruins, rusted machines, soulless cities, and dysfunctional communities, recalling images of the Great Depression with its dustbowls and food lines. 
Mothers and children trapped in poverty in our inner cities; rusted-out factories scattered like tombstones across the landscape of our Nation; an education system, flush with cash, but which leaves our young and beautiful students deprived of all knowledge; and the crime and the gangs and the drugs that have stolen too many lives and robbed our country of so much unrealized potential. (Inaugural)

This post-apocalyptic landscape is dominated by lawlessness, where police officers are under attack and the whole nation is threatened by marauding gangs of killers terrorizing America's main street.

America was shocked to its core when our police officers in Dallas were so brutally executed. [...] Law officers have been shot or killed in recent days in Georgia, Missouri, Wisconsin, Kansas, Michigan and Tennessee. [...] On Sunday, more police were gunned down in Baton Rouge, Louisiana. [...] Thousands of criminal aliens [that] freely roam our streets, do whatever they want to do, crime all over the place. (Nomination Acceptance)

In Trump's discourse, the American body itself is under assault. America is being "poisoned," "crippled," "gutted," "raped," and the threat to America is everywhere:

ISIS has spread across the [...] world. Libya is in ruins, and our Ambassador and his staff were left helpless to die at the hands of savage killers [...]. Iraq is in chaos. Iran is on the path to nuclear weapons. Syria is engulfed in a civil war and a refugee crisis now threatens the West. (Nomination Acceptance)

But it is not enough that America is facing an existential threat from Mexican rapists and ISIS killers. No, it is also becoming a nation of losers. "America can't win anymore," says Trump, more than once. America is becoming a third world country, and worse: "That's when we become Greece. That's when we become a country that's unsalvageable" (Announcement). America is being humiliated and ridiculed around the world, and its unpatriotic president and his Secretary of State are allowing it to happen. 
The degree of deviance from previous discursive norms in Trump's campaign speeches becomes apparent when seen in comparison to the previous Republican candidate, Mitt Romney. In 2012, Romney, who was running on what at the time was considered a hardline immigration policy, told members of the Republican National Hispanic Assembly in Tampa, Florida, that "we must address illegal immigration in a way that is civil but resolute." Adding, "Our country must do a better job of securing its borders," Romney promised, long before Trump, the "construction of a high-tech fence, and investing in adequate manpower and resources" among the Mexican border. Romney attacked Obama as having failed "to address the problems of illegal immigration in America" ((Romney 2011), but he never called the President a traitor. Indeed, in the 100 documents covering Romney's 2012 campaign available on the University of California at Santa Barbara's American Presidency Project website, Romney never uses the word "traitor" or, for that matter, the words "rape" or "rapist(s)", once. Trump uses "traitor(s)" six times to refer to Clinton and/or Obama and refers to "rape" and "rapists" in the context of illegal immigration 15 times in a total of 74 analyzed speeches.

Trump's language of fear is very much relying on the use of negatively charged lexical items. A frequency analysis of the keyword stems 'kill*' and 'murder*,' for example, shows the strong presence of these so-called "devil terms" (Weaver 1953). The words 'kill*' or 'murder*' appear in 57 of the 74 speeches analyzed for a total of 226 occurrences. The three most frequent collocates, i.e., words in the immediate textual vicinity of kill* or murder*, are 'immigrant,' 'illegal,' and 'gang,' which underlines the highly stigmatized narrative of fear in Trump's discourse.

The logic inherent to this approach becomes even more visible when we analyze the occurrence of the keywords 'immigrant' and 'immigrants' in Trump's campaign 
corpus. These words appear 141 times in the corpus and are concentrated in 39 speeches. In 102 cases, 'immigrant*' is preceded by the adjective 'illegal.' The second and third most frequent collocators for immigrant* are 'deported' and 'criminal,' followed by 'killed' ("by an illegal immigrant"). The fourth most frequent collocator is the word "children." Children are being used in only two ways in the context of immigrants. Either they are the victims of illegal immigrants-Trumps refers, e.g., to "the plight of Americans who have lost their children to illegal immigrants" (Jackson, MS, Aug. 24, 2016) —or they are children of Muslim immigrants and as such terrorists. On a number of occasions, Trump claims that "already, hundreds of recent immigrants and their children have been convicted of terrorist activity inside the U.S." (SoHo).

Another frequent word in the vicinity of 'immigrant*' is 'Obamacare.' Here, Trump uses the alleged abuse of the Affordable Care Act by illegal immigrants as a way to stir up the resentment of those Americans who see themselves as playing by the rules but who are overtaken by those who abuse the system and by the politicians enabling such abuse. Trump uses the exact same phrase_-"Obamacare for illegal immigrants"— in five different speeches, saying, for example:

[Hillary Clinton] wants Social Security, Medicare and lifetime welfare for illegal immigrants by making them all citizens. They get taken care of better than our great vets [...]. She wants Obamacare for illegal immigrants. Obamacare is not going to be here much longer, folks. You see what's going on. Regardless. No deportation of Visa overstays. Expanding catch-and-release on the border. (Colorado Spring, Co., Oct. 18, 2016; emphasis mine)

This quote reflects the dangerous genius in Trump's speeches. He manages to start with serving his constituency one piece of political 'red meat' (here, illegal immigrants) but then immediately piles on other highly charged topics such as leniency towards felons, disregard of law and order, and disrespect of veterans of the Armed Forces. He 
establishes causality where none exists, and laces his statements with just enough examples of selected, individual cases to suggest a greater, more universal truth.

By attacking immigrants for allegedly taking advantage of the system, while never mentioning immigrants in a positive context, Trump enforces the stereotypical views held by a large part of the American white working class, who resent these "line cutters" (Hochschild 2016). Trump fully embraces both the pride and the plight of white working-class Americans. By blaming the perceived deteriorating economic circumstances of American workers on deceitful foreign elements enabled by the globalists of the current administration, Trump satisfies deep-seated racial stereotypes and absolves American workers for any mistakes of their own and thus strengthens socially exclusionary tendencies among white voters. By promising to put America First, Trump offers a nativist solution to the challenges of an increasingly diverse, postindustrial society. He uses the expression "America first" 74 times in 42 speeches (total number of speeches in corpus: 74) and places the American worker at the heart of his narrative. Trump explicitly refers to "worker(s)" 184 times in 57 of the 74 speeches analyzed. Interestingly, Trump only starts using the expression "American worker(s)" in his campaign speeches in late August 2016, but then does so very consistently (58 times in 32 speeches).

In the last two months of the election campaign, Trump's America First slogan and his focus on the American worker merge into a pledge to "put American workers first" and the promise that "American workers will be hired to do the job." Within the span of 18 days (Sept. 13 to Sept. 30, 2016), Trump uses this exact same sentence in eleven different speeches. In almost all these instances, the "American workers will be hired to do the job" mantra is embedded in a larger, nationalist narrative promising the rightful return of prosperity to God's chosen people: 
We will rebuild our roads, bridges, tunnels, highways, airports, schools and hospitals. // American cars will travel the roads, American planes will soar in the skies, and American ships will patrol the seas. // American steel will send new skyscrapers into the clouds. // American hands will rebuild this nation - and American energy, harvested from American sources, will power this nation. American workers will be hired to do the job. // We will put new American steel into the spine of this country. // I will fight for every neglected part of this nation and I will fight to bring us all together as Americans. // Imagine what our country could accomplish if we started working together as One People, under One God, saluting One American Flag. (New York, Sept. 15, 2016; emphasis mine)

This description of this American utopia - a rare element in Trump's otherwise dystopian campaign discourse-reminds Americans of the nation's Golden Age of the 1950s and 1960s, eliciting memories of a time when the American heartland was thriving economically and culturally.

Trump proposes a simple solution to the alleged threats to the heartland originating from alien criminals and terrorists: the erection and strengthening of physical boundaries. First, on the country's southern border, "a great wall," "an impenetrable, physical, tall, power[ful], beautiful" (Immigration) wall will stem the tide of rapists and drugs, that "will not only keep out dangerous cartels and criminals, but it will also keep out the drugs and heroin poisoning our youth" (Bangor, ME, Oct. 15, 2016). Second, Trump promises "to keep radical Islamic terrorists the hell out of our country" (Manchester, NH, Oct. 28, 2016) by "suspend[ing] immigration from areas of the world when there is a proven history of terrorism against the United States, Europe or our allies." Trump continues, "the ban will be lifted when we as a nation are in a position to properly and perfectly screen those people coming into our country" (Manchester, NH, June 13, 2016). In a speech on immigration in Phoenix, Trump refers to this screening of immigrants as a "vetting mechanism," saying: "I call it extreme 
vetting right? Extreme vetting. I want extreme. It's going to be so tough, and if somebody comes in that's fine but they're going to be good. It's extreme" (Immigration).

The creation of physical barriers aimed at keeping those who threaten "not only our security but our way of life" out (Manchester, NH, June 13, 2016) is one of the cornerstones of Trump's campaign. But the American heartland is threatened not only by invasive alien others but by homemade enemies of the American way of life as Trump and his supporters understand it. First in line are those not respecting the law. Using the exact same line- - There is no compassion in tolerating lawless conduct. Crime and violence is an attack on the poor, and will never be accepted in a Trump Administration"-in two different speeches (South Bend, WI, Aug. 16, 2016, and Pittsburgh, PA, September 22, 2016), Trump condemns te riots in Milwaukee and Charlotte, linking them to an overall "anti-police atmosphere" created by the ObamaClinton administration. Never mentioning the black victims of the incidents that started the riots, Trump calls the riots "an assault on the right of all citizens to live in security and peace" and identifies "law-abiding African-American citizens" as the "main victims," adding, "It is their jobs, their homes, their schools and communities which will suffer as a result" (West Bend, WI, Aug. 16, 2016).

By depicting black urban communities as lawless territories and AfricanAmericans as in need of protection from themselves, Trump taps into deep-seated stereotypes of black-on-black violence, black poverty, and black hopelessness. Repeatedly referring to Detroit and Chicago, cities besieged by an "epidemic of violence," Trump makes the most cynical of pitches to African-American voters:

I'm going to make it my personal mission to bring opportunity, safety and prosperity to our very, very troubled inner cities. [...] To those hurting and suffering and left behind, I say, what do you have to lose by trying something new? What do you have to lose by voting for Donald Trump for president? What do you 
have to lose? I will fix the problem. I will fix the problem. (Virginia Beach, VA, July 11, 2016)

The questions "What do you have to lose?" and "What the hell do you have to lose?" appear in 27 of the 74 campaign speeches analyzed. A day before the election, and speaking, as usual, to an almost exclusively white audience, Trump asks: "So you live in the inner cities. You're African-American. You're Hispanic. The schools are no good. There are no jobs. And it's totally unsafe. And I say I will fix it. What the hell do you have to lose? I'm going to fix it" (Raleigh, NC, Nov. 7, 2016).

Trump's apparent concern for the economic and physical security of Hispanic and black voters is a thinly-veiled, Nixonesque appeal to the "silent majority" (Phoenix, AZ, Oct. 29, 2016) of Americans looking for law and order to be restored in America. Trump's nomination acceptance speech plays a central role in this narrative. Here, Trump stresses the lawlessness plaguing the nation, stating, "Americans watching this address tonight have seen the recent images of violence in our streets and the chaos in our communities. Many have witnessed this violence personally, some have even been its victims." Trump identifies attacks on police officers as archetypal of un-American behavior - "An attack on law enforcement is an attack on all Americans"—and establishes himself as the sole protector of America's rule of law, stating: "In this race for the White House, I am the law and order candidate." In Trump's discourse, appeals for law and order are always tied to economic benefits. The dialectic is clear: "My plan will begin with safety at home--which means safe neighborhoods, secure borders, and protection from terrorism. There can be no prosperity without law and order" (Nomination Acceptance).

\subsection{The System is Rigged}

Finding a scapegoat for the fact that "the American dream is dead" (Announcement), 
represents the second stage of the jeremiad. By identifying illegal immigrants, Muslim terrorists, and evil foreign empires on the one hand and lawless black Americans on the other hand as two threats to America's physical and economic security and to the nation's very own way of life, Trump has created one of two un-American out-groups that he makes responsible for the nation's decay and for the poor state of the members of the white Trump coalition. But they are not the real culprits, for there is a second, even more vicious group that enables the savages of the first group to rape the America nation and that is to be blamed for the tribulations of the in-group.

This part of the narrative is identity politics par excellence, and it is here where Trump is at his ruthless best, unleashing nothing less than a cultural civil war. Trump leaves no doubt as to who the false prophets are that have caused America's downfall. Americans have been betrayed by their own leaders, by the politicians, and their elitist puppet masters. They are the victims of a corrupt system that is "rigged by big businesses who want to leave our country, fire our workers $[\ldots]$ with absolutely no consequences for them" (SoHo), a government controlled by special interests who "have total control over every single thing [Hillary Clinton] does. She is their puppet, and they pull the strings" (Nomination Acceptance). Trump's anti-elite discourse portrays the country's current leaders as not only stupid and incompetent but also as traitors, claiming that "President Obama has treated Iran with tender love and care and made it a great power" (Foreign Policy) and that [Hillary Clinton] sold out our workers, and our country, for Beijing" (SoHo). To save the nation from the rigged systems, a new leader is needed.

\subsection{Enter the Savior}

After outing and condemning the false prophets of America's ruling elites, Trump enters the third stage of the jeremiad, where he offers himself to the nation as the new, worthy 
leader: "I'm the only one — believe me, I know them all, I'm the only one who knows how to fix it" (Foreign Policy). Trump understands the importance of the status anxiety experienced by white working-class Americans, which is driven by demographic trends that see whites becoming a majority-minority by 2050 and the country's perceived international decline. Promising "a New American Future [where] we will respect the dignity of all Americans - and that means great jobs, great schools, and great neighborhoods (Greenville, NC, Sept. 6, 2016)," Trump appeals to both the patriotism of his voters and their growing sense of economic resentment. The word 'dignity' becomes a central element of Trump's appeal to those who feel left behind by the rapid changes of a global, post-industrial society and who feel ignored by, disconnected from, and even ridiculed by the nation's white elites.

Inserting an autobiographical element typical of the jeremiad, Trump refers to his father, saying, "It's because of him that I learned, from my youngest age, to respect the dignity of work and the dignity of working people. He was a guy most comfortable in the company of bricklayers, carpenters, and electricians and I have a lot of that in me also. I love those people" (Nomination Acceptance). By talking about people who can "fix an engine or [...] can build a wall" (First 100 Days), Trump suggests to his voters that he is one of them, that he - a billionaire from New York City — understands their economic woes.

The rejection of globalization plays a central role in Trump's scapegoating and victimization strategies. He repeatedly refers to an "ideology of globalism that makes them rich while shipping your jobs, your factories, and your wealth to other countries" (Roanoke, VA, Sept. 24, 2016) to establish a binary us-vs.-them logic, in which the alliances of the two presidential candidates are clear. "Hillary Clinton," claims Trump, "believes in globalism - taking jobs from Flint and moving them to other countries. I 
am not running to be President of the world - I am running to be President of the United States. I am running to bring hope to Flint, to Canton, and to every party of this country" (Canton, OH, Sept. 14, 2016).

Trump's economic nationalism connects well with the patriotic self-image of many white working-class (see Williams 2016). His answer to the globalism of Hillary Clinton and her elitist supporters is as simple as unsurprising, it is "Americanism."

\footnotetext{
Our country lost its way when we stopped putting the American people first. We got here because we switched from a policy of Americanism - focusing on what's good for America's middle class - to a policy of globalism, focusing on how to make money for large corporations who can move their wealth and workers to foreign countries all to the detriment of the American worker and the American economy. (SoHo)
}

The appeal to voters who feel left behind economically is of course not a new phenomenon in American political discourse and is indeed a cornerstone of the jeremiad. Both Ronald Reagan and Bill Clinton, for example, applied these strategies successfully to secure the votes of white swing voters (see Austermuehl 2002). The difference, however, between Reagan and Clinton on the one hand and Trump on the other hand was that the latter applied a rigid zero-sum logic and used unparalleled xenophobic and racist language to create two segregated groups fighting over limited economic and cultural resources.

It is also important to note that the plight of the white working class that is the dominant topic of Trump's campaign is not an entirely fictitious description. White working-class Americans have experienced a steep economic decline symbolized by increased mortality rates among white working-class Americans resulting from what Case and Deaton (2020) refer to as "deaths of despair." "I hear so many stories and pleas, from women especially, about drug addiction and opioid use," says Trump, and 
then immediately links the opioid epidemic, which has domestic origins and is fueled by both domestic and foreign sources, to illegal immigration and smuggling from Mexico: "We lose thousands of our fellow Americans every year to opioid use. I will stop the drug inflow from our borders. These drugs come over the border and make their way into our urban and rural communities, and into our suburbs" (Chester Township, PA, Sept. 22, 2016).

On the campaign trail, Trump consistently presents himself as a successful, selfmade businessman. His attire is always the business suit and the power tie, never the checkered shirt, duck-hunting vest, or barn jacket that are so popular among many male political candidates in the United States. His dress symbolizes economic success, and the independence that comes with it-"I don't need anybody's money. [...] I'm really rich" (Candidacy) - appeals directly to white working-class Americans. In this context, it does not really matter how Trump became successful. The important part is that his biography allows him to present himself as the embodiment of the American Dream, an element without which the jeremiad would lose much of its discursive power.

Similarly, in the logic of the jeremiad, the prophet has to show that he is a political outsider. Here, again, Trump uses his biography well, saying on numerous occasions, "I'm not a politician," adding, "[I] never wanted to be a politician, believe me. But, when I saw the trouble our country was in I knew I couldn't stand by and watch any longer." In the fashion of George Washington, Trump takes on the timetested role of the American Cincinnatus who only reluctantly answered the call to run: "I didn't have to do this, believe me. There's nothing easy about it but I had to do it. I love our country" (Gettysburg). Trump also makes full use of the masculinity of the jeremiad, portraying himself as the strong, male protector of America's forgotten 
majority, saying: "I have joined the political arena so that the powerful can no longer beat up on people that cannot defend themselves" (Nomination Acceptance).

Trump's open animosity towards the establishment of the Republican Party further helped to cement his status of a political outsider. As Reicher and Haslam explain, "his failure to follow the rules of politics and his rejection by the political class validated his in-group status in the eyes of an antipolitical audience. Supporters confirmed that he is "one of us," not "one of them" $(2017,15)$.

Trump's in-group credentials are closely linked to his use of politically incorrect language. In the eyes and ears of his supporters, Trump simply "tells it like it is." As a candidate, for example, Trump tweeted: "So many 'politically correct' fools in our country. We have to all get back to work and stop wasting time and energy on nonsense!" (Trump 2015). Plain language use is seen as evidence of Trump's authenticity.

As mentioned above, Trump consistently refers to the dignity of American workers and the lack of respect for them, and the United States in general. According to Williams, this strongly appealed to those American who "feel disrespected, and [who] wanted someone to reflect that and to channel that anger and to channel that sense of disenfranchisement" (Williams 2016). For many white voters, Trump's show of respect was crucial. They were fed up with being told by Barack Obama that "they get bitter, they cling to guns or religion" (Seelye and Zelenyapril 2008) or called "a basket of deplorables" by Hillary Clinton (Chozick 2016), and they could not care less if Trump pronounces Tanzania like Tasmania or if he calls Namibia Nambia. For them, what mattered was that Trump showed them respect, that he said, "I am your voice" (Nomination Acceptance). 


\subsection{Salvation}

Despite its doomsday narrative, the jeremiad is a positive genre- - "a litany of hope," as Sacvan Bercovitch $(2012,11)$ calls it. In the final stage, the prophet always promises his people a better future, but only if they vote for him. However, beyond the promise of making America safe, rich, and great again, Trump does not offer any more details about his vision for the country's better future.

This is where Trump's discourse is again different. While he made full use of the many different facets of the jeremiad — composing a powerful narrative of sin, fear, and absolution, scapegoating not only the current Democratic opposition but the entire political and media elite of the country, and presenting himself as the masculine embodiment of the American dream and as the only possible savior of the nation-he never developed a positive vision of post-election America. While, for example, Bill Clinton's Jeremiah was if not a happy one, then at least a positive one who provided hope and a positive vision for the country's future, Trump's discourse is without hope, without light. His speeches are fixed on, and fixated with, the dark side of the jeremiad. In his discourse, the inherently hopeful nature of the jeremiad turns into a horror story, and instead of the promise of the Fisher King's fertile lands, Trump's first speech as president focuses on "mothers and children trapped in poverty in our inner cities; rusted-out factories scattered like tombstones across the landscape of our Nation; an education system, flush with cash [...]. This American carnage" (Inaugural Address).

American presidents are often referred to as the high priests of America's civil religion (see, e.g., Bellah 1975). Trump, however, never made the transition from prophet to priest — he never even tried to - but instead stayed in permanent campaign mode (see Blumenthal 1982). His first speech as president was the first speech of the 2020 general election campaign, and he has not stopped since. 


\section{Conclusion}

According to a much publicized 2008 report by the U.S. Census Bureau, Americans who self-identify as white and non-Hispanic will no longer represent the majority of the U.S. population by the year 2050 . The same report suggested that as early as 2020, more non-white children than white children will be born in the United States. This trend is seen as the main reason for increased white identity politics and, as a consequence, "many whites now view themselves as an embattled and even disadvantaged group, and this has led to both strong ingroup identity and a greater tolerance for expressions of hostility toward outgroups" (Valentino, Neuner, and Vandenbroek 2016, 25).

Valentino, Neuner, and Vandenbroek $(2016,25)$ suggest that this greater "tolerance for hostile racial rhetoric" precedes the Trump campaign and must rather be seen as a reaction to the election in 2008 of Barack Obama, which "may have ironically provided at least some whites with the perceived moral license to express more critical attitudes about minorities." They argue that "many racial conservatives may notice racially insensitive content, yet do not feel angry or disgusted by it. One reason may be that many feel we have become too sensitive when discussing race." Trump's uncivil discourse and his deliberately politically incorrect actions both exploited and fueled these sentiments, and there is little reason to assume that he will change tactics for the 2020 presidential election.

A large number of whites continue to feel that their heartland is threatened by the above mentioned demographic trends and the growing diversity of the nation. As Creech writes, the notion of the heartland represents "a source of American democratic character that is discursively linked to predominately White communities buoyed by the economic benefits of a post-WWII industrialization" $(2018,6)$. The idea of the heartland "links the economic prosperity of the White working class to the expressions 
of American identity" (ibid.). Rydgren, building on Taggart (2000), highlights the populist dimension of the heartland concept. According to Rydgren, "populist ideology tends to build on an idealized image of a chosen people that is located in a similarly idealized landscape" $(2017,488)$.

This idea is of course central to the logic of the jeremiad, in which the new prophet leads the chosen people back to a heartland restored to its former glory. The jeremiad is a nostalgic genre. It longs for an idealized past, which is characterized by a "homogeneous and genuine way of life" (Rydgren 2017, 488). The American heartland of the past, and that of Trump's speeches, is one where sameness dominates over diversity. Being 'same' is a prerequisite for being part of the chosen people. As Rydgren further explains, "the people inhabiting this imagined heartland constitute 'the people' of populist ideology and rhetoric; those who did not belong to the people of the heartland of the past do not belong to 'the people' of today, either" $(2017,488)$.

The boundaries between "white working-class Americans-particularly toward groups to which they hold themselves superior, such as undocumented immigrants" (Lamont, Park, and Ayala-Hurtado 2017, S162) continue to exist, and Trump continues to create fear among the voters who secured his win in 2016, which the Washington Post comment upon as follows: "After years of an expansive view of America and what it means to be American and pursue the American dream, the president of the United States is determined to carry the water of those who believe this nation is a white nation for white people" (Capehart 2017).

The 2020 election is Trump's to lose. Since 1948, sitting presidents were ousted only three times on eleven occasions. The three presidents preceding Trump where all re-elected with significant margins. With few demographic changes, voter motivation and turnout will again be the Holy Grail of the 2020 election. In 2016, Trump found a 
winning discursive formula that combined economic nationalism with strong racist, xenophobic, and misogynist ethno-nativist appeals to a clearly demarcated in-group of American voters. His verbal behavior during his first three years in office provides no reason at all to think that he will not again apply the normalization strategies discussed in this article.

\section{$6 \quad$ References}

Austermuehl, F. 2002. "'Creating Hope' - Narrative Strategies in Bill Clinton's Rhetoric." In Investigations of Narrative Structures, edited by H W. Drescher, C. Todenhagen and W. Thiele, 129-151. Frankfurt: Peter Lang.

Austermuehl, F. 2019. "On Prophets, Priests and Presidents." Lecture presented at Aston University, Birmingham, UK. March 14.

https://www.facebook.com/astonuniversity/videos/-on-prophets-priests-andpresidents-creating-america-from-the-bully-pulpit-watch/1981216235520269/. Accessed: 7 January 2020.

Baker, P., C. Gabrielatos, M. Khosravinik, M. Krzyżanowski, T. McEnery and R. Wodak. 2008. "A Useful Methodological Synergy? Combining Critical Discourse Analysis and Corpus Linguistics to Examine Discourses of Refugees and Asylum Seekers in the UK Press." Discourse and Society 19 (3): 273-306.

Bellah, R. 1975. The Broken Covenant: American Civil Religion in a Time of Trial. New York: Seabury.

Bercovitch, S. 2012. American Jeremiad. Madison: University of Wisconsin Press.

Blumenthal, S. 1982. The Permanent Campaign. New York: Simon and Schuster.

Burleigh, N. 2019. "How Donald Trump Played the (White) Race Card and Reshaped the Democratic Party." Newsweek Magazine, March 6. https://www.newsweek.com/2019/03/15/trump-race-democrats-identity-politics2020-1352568.html. Accessed: 7 January 2020.

Campbell, K. K. and K. H. Jamieson. 2008. Presidents Creating the Presidency: Deeds Done in Words. Chicago: University of Chicago Press.

Capehart, J. 2017. "The First White President is a 'Bad Dude'." The Washington Post, September 18. https://www.washingtonpost.com/blogs/post- 
partisan/wp/2017/09/18/the-first-white-president-is-a-bad-dude/. Accessed: 7 January 2020.

Case, A. and A. Deaton. 2020. Deaths of Despair and the Future of Capitalism. Princeton, NJ: Princeton University Press.

Chozick, A. 2016. 'Hillary Clinton Calls Many Trump Backers 'Deplorables,' and G.O.P. Pounces." New York Times, September 10. https://www.nytimes.com/2016/09/11/us/politics/hillary-clinton-basket-ofdeplorables.html. Accessed: 7 January 2020.

Coates, T. 2017. "The First White President." The Atlantic, October. https://www.theatlantic.com/magazine/archive/2017/10/the-first-whitepresident-ta-nehisi-coates/537909/. Accessed: 22 December 2019.

Cohen, S. (1972) 2002. Folk Devils and Moral Panics: The Creation of the Mods and Rockers, 3rd ed. London: Routledge.

Creech, B. 2018. "Finding the White working class in 2016: Journalistic discourses and the construction of a political identity." European Journal of Cultural Studies: 1-22. doi: https://doi.org/10.1177/1367549418786413

Fairclough, N. 1992. Language and Power. London: Longman

File, T. 2017. "Voting in America: A Look at the 2016 Presidential Election." U.S. Census Bureau, May 10. https://www.census.gov/newsroom/blogs/randomsamplings/2017/05/voting_in_america.html. Accessed: 23 October 2019.

Gabbatt, A. 2019. "Golden Escalator Ride: The Surreal Day Trump Kicked Off His Bid for President." The Guardian, June 14. https://www.theguardian.com/usnews/2019/jun/13/donald-trump-presidential-campaign-speech-eyewitnessmemories. Accessed: 28 October 2019.

Griffin, R., R. Teixeira and J. Halpin. 2017. Voter Trends in 2016. A Final Examination. Washington, D.C.: Centre for American Progress.

Goodman, L. M. 2014. "Your Vote Matters (To Data Engineers)." Newsweek Magazine, November 4. https://www.newsweek.com/big-brother-predicting-how-you-willvote-282108. Accessed: 22 December 2019.

Hanson, V. D. 2016. "Why Trump Won" Hoover Institution, November 11. https://www.hoover.org/research/why-trump-won. Accessed: 22 December 2019.

Hochschild, A.R. 2016. Strangers in Their Own Land: Anger and Mourning on the American Right, New York: The New Press. 
Kaveny, C. 2016. Prophecy Without Contempt: Religious Discourse in The Public Square. Cambridge, MA: Harvard University Press.

Kennedy, C., M. Blumenthal, S. Clement, J. D. Clinton, C. Durand, C. Franklin, K. McGeeney et al. 2018. "An Evaluation of the 2016 Election Polls in the United States." Public Opinion Quarterly, 82 (1), Spring: 1-33. https://doi.org/10.1093/poq/nfx047. Accessed: 7 January 2020.

Krzyżanowski, M. 2020. "Normalization and/as Discursive Construction of Norms and 'New' Normality: Discursive Shifts of Populism and Neoliberalism." Social Semiotics 30. Special issue: Strategies of Normalization in Public Discourse: Paradoxes of Populism, Neoliberalism and the Politics of Exclusion. PAGES. Krzyżanowski, M. and P. Ledin. 2017. "Uncivility on the Web: Populism in/and the Borderline Discourses of Exclusion." Journal of Language \& Politics, 16 (4): $566-581$.

Lamont, M., B. Y. Park, and E. Ayala-Hurtado. 2017. "Trump's Electoral Speeches and his Appeal to the American White Working Class." The British Journal of Sociology 68 (S1): 153-180. doi: https://doi.org/10.1111/1468-4446.12315

Lichtblau, E. 2017. "C.I.A. Had Evidence of Russian Effort to Help Trump Earlier Than Believed." New York Times, April 6.

https://www.nytimes.com/2017/04/06/us/trump-russia-cia-john-brennan.html. Accessed: 22 December 2019.

McElwee, S., M. McDermott and W. Jordan. 2017. "4 Pieces of Evidence Showing FBI Director James Comey Cost Clinton the Election". Vox, January 11. https://www.vox.com/the-big-idea/2017/1/11/14215930/comey-email-electionclinton-campaign. Accessed: 22 December 2019.

Morgan, S. L., and J. Lee. 2017. "The White Working Class and Voter Turnout in U.S. Presidential Elections, 2004 to 2016." Sociological Science 4: 656-685. doi: $10.15195 / \mathrm{v} 4 . \mathrm{a} 27$

Newkirk, V. R. 2018. "Voter Suppression Is Warping Democracy." The Atlantic, July 17. https://www.theatlantic.com/politics/archive/2018/07/poll-prri-votersuppression/565355/. Accessed: 22 December 2019.

Romney, M. 2011. "Remarks to Republican National Hispanic Assembly in Tampa, Florida." The American Presidency Project, September 2. https://www.presidency.ucsb.edu/documents/remarks-republican-nationalhispanic-assembly-tampa-florida. Accessed: 7 January 2020. 
Rydgren, J. 2017. "Radical right-wing parties in Europe. What's populism got to do with it?" Journal of Language and Politics 16(4). 485-496. doi: https://doi.org/10.1075/jlp.17024.ryd.

Seelye, K. Q. and J. Zelenyapril. 2008. "On the Defensive, Obama Calls His Words IllChosen." New York Times, April 13. https://www.nytimes.com/2008/04/13/us/politics/13campaign.html. Accessed: 30 December 2019.

Smith A. and M. Higgins. 2020. TBC. Social Semiotics 30, 2020 - Special issue: Strategies of Normalization in Public Discourse: Paradoxes of Populism, Neoliberalism and the Politics of Exclusion. PAGES.

Stein, J. 2017. "A New Tell-All about the Clinton Campaign is a Searing Indictment of the Candidate Herself." Vox, April 24. https://www.vox.com/2017/4/24/15369452/clinton-shattered-campaign. Accessed: 7 January 2020.

Taggart, P. 2000. Populism. Buckingham: Open University Press.

Trump, D. J. 2015. Twitter Post. August 8, 2015. 5:29 a.m. https://twitter.com/realdonaldtrump/status/629992743788523520?lang=en. Accessed 7 January 2020.

Valentino, N. A., F. G. Neuner, and L. M. Vandenbroek. 2018. "The Changing Norms of Racial Political Rhetoric and the End of Racial Priming. The Journal of Politics, 80 (3): 757-771.

van Dijk, T. 2008. Discourse and Power. New York: Palgrave Macmillan.

Weaver, R. M. 1953. The Ethics of Rhetoric. Chicago: H. Regency.

Williams, J. 2016. "Why the White Working Class Voted for Trump." Harvard Business Review, November 18. https://hbr.org/ideacast/2016/11/why-the-whiteworking-class-voted-for-trump?referral $=03758 \& \mathrm{~cm} \_v c=r$ _item_page.top_right. Accessed: 7 January 2020.

Wodak, R. 2015. The Politics of Fear. What Right-Wing Populist Discourses Mean. London: Sage.

Yglesias, M. 2017. "What Really Happened in 2016, in 7 Charts." Vox, September 18. https://www.vox.com/policy-and-politics/2017/9/18/16305486/what-really-happenedin-2016. Accessed: 22 December 2019. 


\subsection{Sub-corpus 1}

Remarks Announcing Candidacy for President in New York City, June 16, 2015 (Announcement)

Remarks on Foreign Policy in Washington, DC, Apr. 27, 2016 (Foreign Policy)

Remarks at Trump SoHo in New York City, June 22, 2016 (SoHo)

Address Accepting the Presidential Nomination at the Republican National Convention in Cleveland, OH, July 21, 2016 (Nomination Acceptance)

Remarks on Immigration at the Phoenix Convention Center in Phoenix, AZ, Aug. 31 2016 (Immigration)

Remarks at the South Florida Fair Expo Center in West Palm Beach, FL, Oct. 132016 (West Palm Beach)

Remarks on Proposals for the First 100 Days in Office, Gettysburg PA, Oct. 222016 (First 100 Days)

Remarks in New York City Accepting Election as 45th President, Nov. 92016

(Victory)

Inaugural Address, Washington, DC, Jan. 20, 2017 (Inaugural)

\subsection{Sub-corpus 2}

Remarks Announcing Candidacy for President in New York City, June 16, 2015

Remarks at the AIPAC Policy Conference in Washington, DC, March 21, 2016

Remarks on Foreign Policy in Washington, DC, Apr. 27, 2016

Remarks at Saint Anselm College in Manchester, New Hampshire, June 13, 2016

Remarks at Trump SoHo in New York City

Remarks in Virginia Beach, Virginia, July 11, 2016

Remarks Introducing Governor Mike Pence as the 2016 Republican Vice Presidential Nominee in New York City, July 16, 2016

Address Accepting the Presidential Nomination at the Republican National Convention in Cleveland, Ohio, July 21, 2016

News Conference in Doral, Florida, July 27, 2016

Remarks at the KI Convention Center in Green Bay, Wisconsin, Aug. 5, 2016

Remarks to the Detroit Economic Club, Michigan, Aug. 8, 2016 
Remarks at a Rally at the University of North Carolina in Wilmington, Aug. 9, 2016

Remarks at Erie Insurance Arena in Erie, Pennsylvania, Aug. 12, 2016

Remarks at Youngstown State University in Youngstown, Ohio, Aug. 15, 2016

Remarks at the Washington County Fair Park in West Bend, Wisconsin, Aug. 162016

Remarks at the Charlotte Convention Center in Charlotte, North Carolina, Aug. 182016

Remarks at the Summit Sports and Ice Complex in Dimondale, Michigan, Aug. 192016

Remarks at Luedecke Arena in Austin, Texas, Aug. 232016

Remarks at the Mississippi Coliseum in Jackson, Mississippi, Aug. 242016

Remarks at the XFinity Arena in Everett, Washington, Aug. 302016

Remarks on Immigration at the Phoenix Convention Center Phoenix, Arizona, Aug. 31 2016

Remarks to the American Legion in Cincinnati, Ohio, Sept. 12016

Remarks at the Roberts Centre in Wilmington, Ohio, Sept. 12016

Remarks at Great Faith International Ministries in Detroit, Michigan, Sept. 32016

Remarks at a Rally Greenville Convention Center Greenville North Carolina, Sept. 6 2016

Remarks at the Union League of Philadelphia in Philadelphia, Pennsylvania, Sept. 7 2016

Remarks at the Cleveland Arts and Social Sciences Academy, Ohio, Sept. 82016

Remarks to the 11th Annual Values Voter Summit in Washington, DC, Sept. 92016

Remarks at a Rally at the Pensacola Bay Center in Pensacola, Florida, Sept. 92016

Remarks at the US Cellular Center in Asheville, North Carolina, Sept. 122016

Address to the National Guard Association Baltimore, Maryland, Sept. 122016

Remarks at Aston Community Center in Aston, Pennsylvania, Sept. 132016

Remarks at Seven Flags Event Center in Des Moines, Iowa, Sept. 132016

Remarks at a Rally at Canton Memorial Civic Center Canton, Ohio, Sept. 142016

Remarks to the Economic Club of New York at the Waldorf Astoria, Sept. 152016

Remarks at a Rally at the James L. Knight Center Miami, Florida, Sept. 162016

Remarks at the Remembrance Project Luncheon Omni Houston Hotel, Texas, Sept. 17 2016

Remarks at High Point University in High Point, North Carolina, Sept. 202016

Remarks at a Rally at Sun Center Studios Chester Township, Pennsylvania, Sept. 22 2016

Remarks at the Shale Insight TM Conference Pittsburgh, Pennsylvania, Sept. 222016 
Remarks at a Rally at Berglund Center in Roanoke, Virginia, Sept. 242016

Remarks at a Rally at the Mid-America Center in Council Bluffs, Iowa, Sept. 28, 2016

Remarks at a Rally in Bedford, New Hampshire, Sept. 292016

Remarks at the Suburban Collection Showplace in Novi, Michigan, Sept. 302016

Remarks at the Pueblo Convention Center in Pueblo, Colorado, Oct. 32016

Remarks at the Budweiser Events Center in Loveland, Colorado, Oct. 32016

Remarks at Prescott Valley Event Center in Prescott Valley, Arizona, Oct. 42016

Remarks at Henderson Pavilion in Henderson, Nevada, Oct. 52016

Remarks at the Reno-Sparks Convention Center in Reno, Nevada, Oct. 52016

Excerpts of Remarks at Aaron Bessant Park in Panama City, Florida, Oct. 112016

Remarks at the Southeastern Livestock Pavilion in Ocala, Florida, Oct. 122016

Remarks at the Renaissance Hotel in Columbus, Ohio, Oct. 132016

Remarks at the South Florida Fair Expo Center West Palm Beach, Florida, Oct. 132016

Remarks at the Cross Insurance Center in Bangor, Maine, Oct. 152016

Remarks at Toyota of Portsmouth in Portsmouth, New Hampshire, Oct. 152016

Remarks at the KI Convention Center in Green Bay, Wisconsin, Oct. 172016

Remarks at the Norris-Penrose Event Center in Colorado Springs, Colorado, Oct. 18 2016

Remarks at the Delaware County Fairgrounds in Delaware, Ohio, Oct. 202016

Remarks at the Davis Event Center in Fletcher, North Carolina, Oct. 212016

Remarks at the Newtown Athletic Club Newtown, Pennsylvania, Oct. 212016

Remarks on Proposals for the First 100 Days in Office, Pennsylvania, Oct. 222016

Remarks at the Collier County Fairgrounds in Naples, Florida, Oct. 232016

Remarks at McGlohon Theatre in Charlotte, North Carolina, Oct. 262016

Remarks at the Champions Center Expo in Springfield, Ohio, Oct. 272016

Remarks at Radisson Armory in Manchester, New Hampshire, Oct. 282016

Remarks at the Jeffco Fairgrounds Event Center in Golden, Colorado, Oct. 292016

Remarks at the Phoenix Convention Center in Phoenix, Arizona, Oct. 292016

Remarks at Macomb Community College Warren, Michigan, Oct. 312016

Remarks on Obamacare in Valley Forge, Pennsylvania, Nov. 12016

Remarks at the Central Florida Fairgrounds in Orlando, Florida, Nov. 22016

Remarks at the Bayfront Park Amphitheater in Miami, Florida Nov 2. 2016

Remarks at J.S Dorton Arena in Raleigh, North Carolina, Nov. 72016

Remarks in New York City Accepting Election as 45th President, Nov. 92016 